\title{
AOR
}

Selected Papers of \#AoIR2020:

The 22nd Annual Conference of the Association of Internet Researchers Virtual Event / 13-16 Oct 2021

\section{\#FAITHANDFITNESSCOLLIDE: SPREADING THE WORD OF MULTILEVEL MARKETING IN CHRISTIAN WOMEN'S FITNESS INSTAGRAM POSTS}

\author{
Kai Prins \\ University of Wisconsin - Madison \\ Mariah Wellman \\ University of Utah

\section{Introduction}

With the emergence of the coronavirus in 2020 leading to the closing of gyms and churches, along with the "she-cession" in which women disproportionately left the workforce (Hammer, 2021), women have increasingly turned to fitness-based multilevel marketing (MLM) for a sense of purpose and community - and money. MLM fitness companies like Beachbody, for example, saw a 300\% increase in subscribers following the pandemic in 2020 (Haithman, 2020). Although MLMs encourage their distributors to think of themselves as "independent entrepreneurs," these companies demand fealty and while this puts all the women who participate in a double bind where they are caught between entrepreneurship and the parent company, we are especially interested in the quandary facing the Christian women who participate. Bound to company, family, and God, they must still position themselves as free agents and strong women to build their "fitness ministry" (Coach 8, 2020) and close the sale.

We look at Beachbody because the company attracts the form of "muscular postfeminist evangelism" that we name and analyze in this paper, providing a convenient network and self-contained program where one can go to encounter the Divine through their upline and build their flock through their downline - participants receive a built-in community, instructions on how to behave properly, and the opportunity to spread the Word and lead others. They are, essentially, converted into fitness missionaries while also spreading the Word of God. We turn to Instagram for this analysis because women can share a window into their lives while interacting with the commenters. Instagram

Suggested Citation (APA): Prins, K. \& Wellman, M. (2021, October). \#FaithandFitnessCollide: Spreading the Word of Multilevel Marketing in Christian Women's Fitness Instagram Posts. Paper presented at AolR 2021: The 22nd Annual Conference of the Association of Internet Researchers. Virtual Event: AolR.

Retrieved from http://spir.aoir.org. 
offers a place where they can establish themselves as "authentic" while also carefully managing their brands.

\section{Literature Review \& Research Questions}

This paper contributes to the scant research on multilevel marketing within the communication discipline. Despite its rhetorical power and social impact, MLM remains an under-studied business model outside of business and advertising journals (e.g. Sparks \& Schenk, 2006; Keep \& Nat, 2014) and anthropological accounts of MLM's impact on the Global South (e.g. Cahn, 2009; Droney, 2016). Our analysis explores the tensions between the "emancipatory potential of feminine masquerade" in MLM (Waggoner, 1997) and the required submission of women to both family and God in Christianity. We extend the framework of "evangelical entrepreneurial femininity" (Sullivan \& Delaney, 2017) by asking how fitness specifically complicates or shepherds the relationship between the independent entrepreneur, the MLM, and the patriarchal foundation of her religious practices. We suggest that, just as "muscular Christianity" remasculinized a feminized religious sensibility in the late $19^{\text {th }}$ century (Maddux, 2012), muscular postfeminist evangelism gives Christian women access to roles otherwise conceived of as masculine. We look specifically at how Christian women navigate the potential shame of occupying a masculine economic role and a muscular body by reframing fitness MLMs like Beachbody as an opportunity to fulfill God's plan and (re)inhabit the home.

\section{Methods}

This study stems from a larger project investigating Beachbody coaches' selfpresentation on Instagram during the COVID-19 pandemic (Authors, forthcoming). We examined ten Instagram accounts run by Beachbody coaches whose profile name or bio included one of the following terms: God, Jesus, Faith, Believer, or a specific denomination (ex. Latter-day Saint). We collected all posts published between July 1 and December 31, 2020, and conducted a constant comparative analysis (Charmaz, 2014) to explore trends related to religion, womanhood, and fitness.

We selected constant comparative analysis because it is a qualitative method that encourages researchers to stay engaged with the material through many months of collection. The method categorizes and compares data through rounds of open, focused, and axial coding (Charmaz, 2014). We split the ten accounts in half, first open coding five accounts each. Then, we met and discussed broad patterns before selecting the most relevant themes to return to during focused coding. Finally, we met a second time and discussed specific patterns developed during focused coding and selected examples of each pattern which are discussed in the findings below.

\section{Preliminary Findings \& Discussion}

The promise of building a "fitness ministry" and becoming a better, healthier wife and mother allows Christian Beachbody coaches to muscle through shame: about poor body image; about failure to perform motherhood properly (including the shame of a medicated/hospitalized birth, not breastfeeding, or miscarriage); about how 9-5 work 
gets in the way of prioritizing husband, children, or home. What is most interesting in this case study, however, is how these women invoke shame around their desires to become an entrepreneur - and specifically one who participates in MLM - and to become "fit." Only a few women mention Beachbody by name, choosing instead to talk around the brand by positioning themselves as the CEOs of their own businesses and linking to Google forms to collect information from followers interested in coaching. When they do speak of Beachbody, they do so by first explaining the shame they felt about pursuing fitness, especially through an MLM. They also describe their internal struggles with the desire to sign up for an at-home fitness program, ostensibly because a focus on building muscle demonstrates a turn away from God and toward one's navel, as well as a repudiation of the soft, womanly body expected of a good Christian woman.

These women use their public declarations of shame to counter potential accusations of ungodliness in two specific ways: first, they describe how they discovered that resisting fitness entrepreneurship was an act of resisting God's plan (itself a shameful action). Then, they detail how fitness entrepreneurship, specifically through MLM, has allowed them to enact Christian womanhood more ideally. Reframing Beachbody as an opportunity to build "fitness ministries" allows these women to evangelize from home while building the temple that is the body that can birth and raise children and serve one's husband (or, in the case of the few single women we studied, a temple to the potential of Christian wife- and motherhood). By using their bodies to model both the Book (the Bible) and the (Beachbody) Program, these women can communicate the Word of both God and the company, overcoming objections from their followers and growing their downlines.

\section{References}

Cahn, P. S. (2008). Consuming class: multilevel marketers in neoliberal Mexico. Cultural Anthropology, 23(3), 429-452.

Charmaz, K. (2014). Constructing grounded theory: A practical guide through qualitative analysis (2nd ed.). Sage.

Droney, D. (2016). Networking health: multi-level marketing of health products in Ghana. Anthropology \& medicine, 23(1), 1-13.

Haithman, D. (2020, May 18). Beachbody sees gains. Retrieved from https://labusinessjournal.com/news/2020/may/18/beachbody-sees-gains/.

Hammer, B. (2021, January 25). How to fix women's jobs during the covid-19 pandemic. Retrieved from https://time.com/5932620/women-covid-19-jobs/.

Keep, W. W., \& Vander Nat, P. J. (2014). Multilevel marketing and pyramid schemes in the United States. Journal of Historical Research in Marketing.

Maddux, K. (2012). The feminized gospel: Aimee Semple McPherson and the gendered performance of Christianity. Women's Studies in Communication, 35(1), 42-67. 
Sparks, J. R., \& Schenk, J. A. (2006). Socialization communication, organizational citizenship behaviors, and sales in a multilevel marketing organization. Journal of Personal Selling \& Sales Management, 26(2), 161-180.

Sullivan, K. R., \& Delaney, H. (2017). A femininity that 'giveth and taketh away': The prosperity gospel and postfeminism in the neoliberal economy. Human Relations, 70(7), 836-859.

Waggoner, C. E. (1997). The emancipatory potential of feminine masquerade in Mary Kay cosmetics. Text and Performance Quarterly, 17(3), 256-272. 